\title{
Comparative Bioaccumulation of PAH and BTEX in Malapterurus electricus (Siluriformes: Malapteruridae) and its Enteric Parasite, Electrotaenia malopteruri Sampled from Lekki Lagoon, Lagos, Nigeria
}

\author{
P. O. Isiborl* (D), E. Akeredolu², O. B. Samuel ${ }^{3}$, A. Abayomi $^{4}$, F. Olaleru², B. Akinsanya ${ }^{2}$ (D), \\ P. Emezie E. F. N. Are $^{2}$, and J. K. Saliu ${ }^{2}$ \\ ${ }^{1}$ Department of Biological Sciences, Covenant University, Ota, Ogun State, Nigeria \\ ${ }^{2}$ Department of Zoology, University of Lagos, Akoka, Lagos, Nigeria \\ ${ }^{3}$ Department of Marine Sciences, University of Lagos, Akoka, Lagos, Nigeria \\ ${ }^{4}$ Department of Chemistry, University of Lagos, Akoka, Lagos, Nigeria \\ *e-mail: patrickisibor007@gmail.com
}

Received: April 18, 2020 - Accepted: June 14, 2020 - Distributed: November 30, 2021

(With 6 figures)

\begin{abstract}
Contamination of Lekki lagoon by petrogenic chemicals such as polycyclic aromatic hydrocarbons (PAH) and benzene, toluene, ethylbenzene, and xylene (BTEX) has been widely reported. The study was aimed at investigating the bioaccumulation of PAH and BTEX in Malapterurus electricus collected from Lekki lagoon in Lagos, Nigeria. BTEX was analyzed in the intestine, water, and sediment samples using 8260B Agilent 7890B gas chromatograph coupled to a mass spectrometer (GC-MS). While PAHs were tested in the same media using a gas chromatograph coupled to a flame ionization detector (GC-FID). Histopathological analysis of the fish intestine was conducted using haematoxylin and eosin (H\&E) stains. Parasite intensity, antioxidant enzymes, and lipid peroxidation activities were investigated in the fish. The parasitic infection detected in Malapterurus electricus was Electrotaenia malopteruri. The parasite showed weak and no depurative capacities for BTEX and PAH respectively. The decrease in superoxide dismutase (SOD), catalase (CAT), and reduced glutathione (GSH) in conjunction with an increase in Malondialdehyde (MDA) characterized relatively higher susceptibility among the male fish. Varieties of tissue injuries increased with the standard length of the fish groups. Results suggest that lengthier and uninfected M. electricus were more susceptible to PAH in Lekki lagoon than the shorter and infected ones. The study demonstrated a promising tendency of the enteric parasite, E. malopteruri to depurate chlorobenzene, ethylbenzene, o-xylene, $\mathrm{m}+\mathrm{p}-\mathrm{xylene}$, and 1,4-dichlorobenzene from the intestine of its host fish, $M$. electricus, while PAHs were poorly mediated by the parasite.
\end{abstract}

Keywords: bioaccumulation, acenaphthylene, pyrene; electric fish, oxidative stress, histopathology.

\section{Bioacumulação comparativa de HAP e BTEX em Malapterurus electricus (Siluriformes: Malapteruridae) e seu parasita entérico, Electrotaenia malopteruri, coletado na lagoa Lekki, Lagos, Nigéria}

\section{Resumo}

A contaminação da lagoa Lekki por produtos químicos petrogênicos, como hidrocarbonetos aromáticos policíclicos (HAP) e benzeno, tolueno, etilbenzeno e xileno (BTEX), foi amplamente relatada. O estudo teve como objetivo investigar a bioacumulação de HAP e BTEX em Malapterurus electricus, coletados na lagoa Lekki, em Lagos, Nigéria. O BTEX foi analisado no intestino, na água e nas amostras de sedimento usando o cromatógrafo de gás Agilent 7890B 8260B acoplado a um espectrômetro de massa (GC-MS). Já os HAP foram testados no mesmo meio utilizando cromatógrafo gasoso acoplado a detector de ionização de chama (GC-FID). A análise histopatológica do intestino do peixe foi conduzida usando colorações de hematoxilina e eosina (H\&E). Intensidade de parasitas, enzimas antioxidantes e atividades de peroxidação lipídica foram investigadas nos peixes. A infecção parasitária detectada em Malapterurus electricus foi Electrotaenia malopteruri. O parasita mostrou fraca e nenhuma capacidade depurativa para BTEX e HAP, respectivamente. A diminuição da superóxido dismutase (SOD), catalase (CAT) e glutationa reduzida (GSH), em conjunto com o aumento do Malondialdeído (MDA), caracterizou a suscetibilidade relativamente maior entre os peixes machos. Variedades de lesões nos tecidos aumentaram com o comprimento padrão dos grupos de peixes. Os resultados sugerem que os M. electricus maiores e não infectados foram mais suscetíveis aos HAP na lagoa Lekki do que os menores e infectados. O estudo demonstrou uma tendência promissora do parasita entérico E. malopteruri de depurar clorobenzeno, etilbenzeno, o-xileno, $\mathrm{m}+\mathrm{p}$-xileno e 1,4-diclorobenzeno do intestino de seu peixe hospedeiro, M. electricus, enquanto os HAP foram mal mediados pelo parasita.

Palavras-chave: bioacumulação, acenaftileno, pireno, peixes elétricos, estresse oxidativo, histopatologia. 


\section{Introduction}

The rise in petroleum exploration following the rapid growth of the petroleum industry in Nigeria has resulted in oil spills from leakage of tankers, pipelines, storage, and dumping of waste petroleum products which has been major contamination to the aquatic environment. Consequently, polycyclic aromatic hydrocarbons (PAH), and benzene, toluene, ethylbenzene, and xylene (BTEX) from oil production in the downstream sector have been extensively observed in various components of the Nigerian environment (Akpoborie et al., 2008; Guimaraes et al., 2010; Osu and Asuoha, 2010). Benzene could pollute the air as a result of fuel combustion, such as burning of wood, coal, and petrol. Benzene is also used as a substitute for lead in fuel for enhanced fuel efficiency. It is also used in the fabrication of other chemicals including ethylbenzene, cymene, cyclohexane, nitrobenzene, and alkylbenzene. It is also a constituent of resins, adhesives, nylon, rubbers, lubricants, dyes, detergents, drugs, explosives, and pesticides. Toluene is also a common indoor contaminant, used in common household products such as paints, adhesives, and nail polish, as well as from cigarette smoke. Ethylbenzene and xylene are used in making polymers and plastics, pesticides, solvents, paints, varnishes, automotive products, adhesives, etc.

Contamination of aquatic ecosystems by petrogenic chemicals such as PAH and BTEX has been detected in sediment, water, and aquatic flora and fauna worldwide (Smith and Guentzel, 2010), and also in Nigerian water bodies (Enuneku and Ilegomah, 2015), such as Lekki lagoon (Doherty and Otitoloju, 2016). The largest petroleum product depots in Nigeria with a large network of pipelines distribute petroleum products all over the country. Consequently, Lekki lagoon has been subjected to incremental oil spillages due to numerous tank farms which facilitate importation, storage, and distribution of petroleum products all over Nigeria (Adeyemi et al., 2009; Akinsanya et al., 2015).

Anyakora et al. (2004) also reported high levels of polycyclic aromatic hydrocarbons (PAH) in the water and sediment of the lagoon, which was linked to oil spill incidents from the facilities around the lagoon (Adeyemi et al., 2009). Petrogenic hydrocarbons earlier detected in the lagoon were also attributed to predominant petroleum activities around the lagoon (Akinsanya et al., 2014). It was documented that unacceptable levels of BTEX had impacted negatively on the macrobenthic community structure of the Lagos segment of the lagoon (Doherty and Otitoloju, 2016). Recently, Akinsanya et al. (2018) reported high concentrations of polycyclic aromatic hydrocarbons (PAH) they detected in prawns (Macrobrachium vollenhovenii), pink shrimps (Penaeus notialis), and low molecular weight $\mathrm{PAH}$ in black chin tilapia (Saratherodon melanotheron) and its parasite, Aspidogastrea africanus.

Ships and motorized boats used for the importation, and exportation of petroleum-related products also contribute immensely to the total deposit of hydrocarbons in the aquatic ecosystem. Despite these debilitating perturbations on the water body, an appreciable percentage of Lagos populace still depends on the lagoon for potable and recreational water. Lekki lagoon also serves as a source of fish for animal protein needs.

Electric catfish (Malapterurus electricus) is a predominant fish species of high commercial value in Lekki lagoon. The fish species is highly sensitive to petrogenic stressors such as BTEX and PAH (Azqueta et al., 2009), as it readily bio-accumulates the xenobiotics in its lipidrich tissues. These chemicals may elicit oxidative stress (Akinsanya et al., 2014; Isibor, 2017) and histopathological injuries (Akinsanya et al., 2015; Akinsanya et al., 2018) which may serve as indices in estimating the exposure of the fish to the toxicants and serve as a guideline in the protection of the entire aquatic habitat. Furthermore, the synergy of PAH and BTEX toxicity may elicit immunosuppression in fish (Piano et al., 2004), which can culminate in unprecedented parasitic infections. Thus, parasite intensity in fish may also serve as indices in estimating the extent of pollution in an aquatic environment. Accumulation of contaminants by gastrointestinal parasites from their host fish may also ameliorate the concentration in the host (Bosch et al., 2015). Antioxidant biomarkers are good environmental monitoring tools in aquatic studies, as they give an early warning signal on the toxicology of xenobiotics at the molecular level (Farombi et al., 2007; Soundararajan et al., 2009). It, therefore, guarantees proactive measures in safeguarding human health and environmental integrity.

There have been varied views on the most debilitating constituent of crude oil as reported in the literature that emphasized PAH, others focused on BTEX as the major toxicant (Azqueta et al., 2009; Akinsanya et al., 2018). A combined study on the comparative toxicity of these chemicals is however lacking. This study was therefore aimed at comparatively assessing the bioaccumulation of BTEX and PAH in M. electricus and its gut parasite, E. malopteruri using antioxidant, and histopathological biomarkers as indices of toxicological assessment.

\section{Materials and Methods}

\subsection{Study area}

Lekki lagoon (Figure 1) supports a major fishery in Nigeria. The lagoon is located in Lagos State Nigeria ( $4^{\circ} 00^{\prime}$ and $4^{\circ} 15^{\prime} \mathrm{E}$ and $6^{0} 25^{\prime}$ and $\left.6^{0} 37^{\prime} \mathrm{N}\right)$. It has a surface area of about $247 \mathrm{~km}^{2}$ and it is average $6.4 \mathrm{~m}$ depth. Lekki lagoon takes source from the River Oni and discharges Northeastwards into River Oshun and North-westwards into Saga River. The vegetation around the lagoon comprises shrubs, raphia palms- Raphia sudanica, oil palms- Elaeis guineensis, and coconut palms- Cocos nucifera.

\subsection{Collection and analysis of specimens}

A total of 134 fish samples identified as M. electricus (102 males and 32 females) were procured at landing from the fishermen at the lagoon. The samples were preserved in chest coolers fortified with ice packs and taken to the 


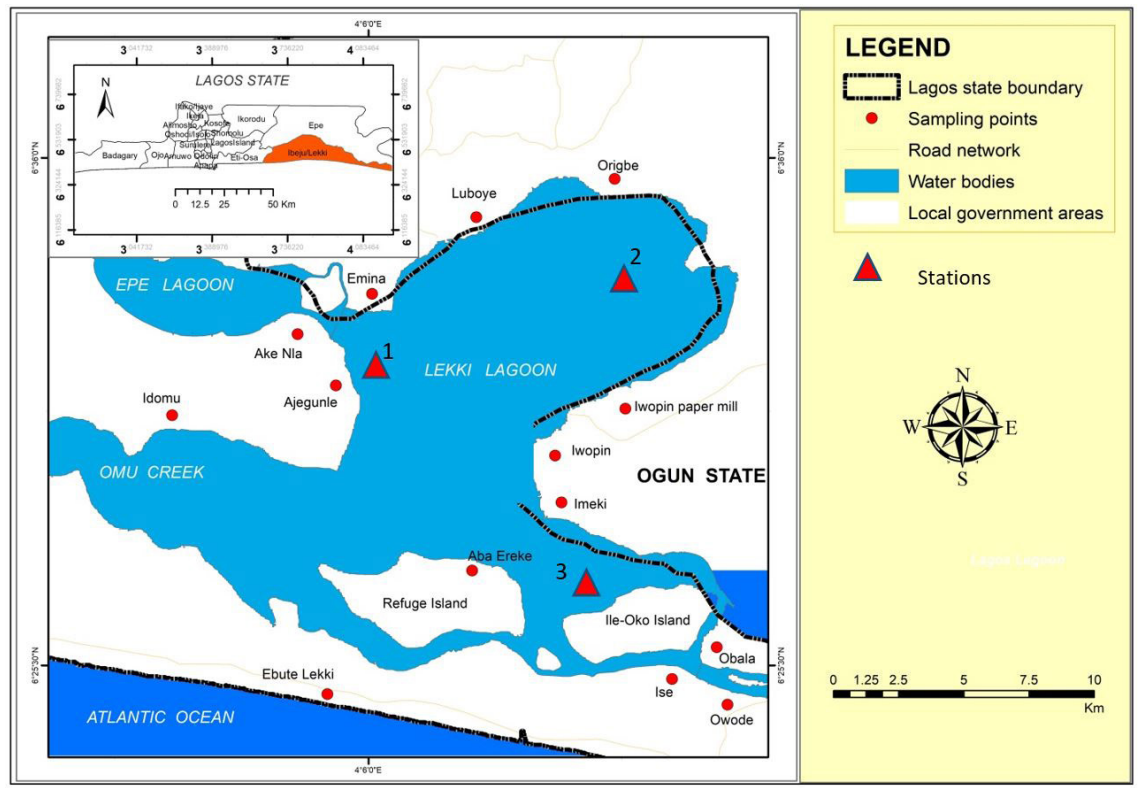

Figure 1. Map of Lekki Lagoon showing sampling stations.

laboratory of the Zoology Department, University of Lagos for proper identification using Olaosebikan and Raji (1998); and Idodo-Umeh (2003). Fish sampling was done ad-libitum throughout the sampling experiment to negate the sexual possible sexual bias during capture. The intestine of the fishes was excised using sterile blades. The enteric parasites were collected in a Petri dish containing a normal saline solution. The parasitological analysis of the specimens was carried out on-site for the validity of the observations.

Surface water and bottom sediment samples were collected at 3 strategic stations of contamination at the lagoon. The locations labeled Stations 1, 2, and 3, had 7 sub-stations each from which surface water and bottom sediment samples were collected and mean values evaluated to represent the values of each station. This procedure was done monthly for 7 months (February-August 2018). Surface water samples were collected using clean $1 \mathrm{~L}$ sampling bottles. The samples were kept in flasks stocked with ice packs and transported to the laboratory of the Department of Marine Sciences, University of Lagos, where they were further refrigerated at $-10{ }^{\circ} \mathrm{C}$ before laboratory analysis.

Bottom sediment samples were collected with the aid of Van Veen grab $(15 \times 15 \times 12 \mathrm{~cm})$ at each location and were stored immediately in aluminum foil paper before analysis. Afterward, the soil sample was air-dried at room temperature for $48 \mathrm{hrs}$ and passed through a sieve of the mesh size $1 \mathrm{~mm}$. We then weighed $10 \mathrm{~g}$ of the prepared soil sample into a test tube. Then we extracted it with $10 \mathrm{~mL}$ of methanol.

\subsection{Measurement of fish morphometrics}

The standard length of fish was measured using a meter rule to the nearest $0.1 \mathrm{~cm}$. After draining excess water the mouth and blot drying, the weight of the fish was obtained to the nearest $0.1 \mathrm{~g}$ using a standard loading Denward balance, sex determination of the fish species was done by physical inspection of eggs and the presence of an intromittent organ on the ventral side before the anal fin is indicative of a female species. Sex was then determined by the presence or absence of testis or ovaries through dissection.

Collected parasites were preserved in $8 \%$ alcohol, counted, recorded, and identified at the laboratory of the Zoology Department, University of Lagos, Nigeria using Bruno et al. (2006) as the identification manual.

\subsection{Physicochemical analysis}

Horiba $\mathrm{U}_{12}$ multi-checker water quality meter was used in situ to determine levels of $\mathrm{pH}$, conductivity, turbidity, salinity, temperature, and dissolved oxygen of the water samples collected at each of the three sampling stations.

\subsubsection{Sample preparation}

Sediment samples were sieved through $10 \mu \mathrm{m}$ mesh to obtain fine particles. The samples were air-dried for $24 \mathrm{~h}$ before analysis. Each fish specimen was eviscerated and filleted and the intestine was removed. $200 \mathrm{~g}$ of fish intestinal tissue and parasites (pooled to make up 200g) were mechanically homogenized separately using a kitchen blender (Sonik Japan, Model SB-1871). The homogenized samples were preserved in a refrigerator at $-20^{\circ} \mathrm{C}$.

\subsubsection{Analysis of BTEX}

The extraction method was carried out on the water, sediment, and homogenized fish intestine and parasite tissue samples by employing the modified methods of ASTM D3328 and ASTM 3415, as recommended by Durand et al. (2004) and as later modified by Alani et al. 
(2012). A homogenized intestinal tissue sample (1.0 g) was weighed into a $250 \mathrm{~mL}$ capacity beaker of borosilicate material and $100 \mathrm{~mL}$ of redistilled hexane: dichloromethane (3: 1) was added to the tissue. The mixture in a beaker was centrifuged at $3400 \mathrm{rpm}$ (using Sigma, Goettingen, Germany) to extract the hydrocarbon for about $2 \mathrm{~h}$. The organic layer was filtered into the $250 \mathrm{~mL}$ capacity borosilicate beaker. The filtrate was dehydrated by passing it through a funnel containing the anhydrous sodium sulfate.

Dichloromethane and sodium sulfate were used in absorbing the water and surrogate standards were used for measuring the recovery of the analysis. In the case of soil and intestinal tissue, the solvent is extracted from the solid matrix through centrifugation. The extract was then filtered through gravity flow columns of silica, alumina to remove highly polar compounds. The filtered extract was concentrated to $1 \mathrm{~mL}$ for water and sediments or $300 \mu \mathrm{L}$ for tissues. The aliquot of each extract $(250 \mu \mathrm{L})$ was fractionated using high-performance liquid chromatography (Model 8800 HPLC) at a wavelength of $22.250 \mathrm{~nm}$. Afterward, BTEX was analyzed in intestine tissue, sediment, and water samples using Environmental Protection Agency (EPA) method 8260B Agilent 7890B gas chromatograph coupled to a mass spectrometer (GC-MS). The stationary phase of separation of the compounds used was a DB-5 capillary column coated with 95\% dimethyl - 5\% diphenyl polysiloxane $(30 \mathrm{~m}$ length $\mathrm{x} 0.32 \mathrm{~mm}$ diameter $\mathrm{x} 1.0 \mu \mathrm{m}$ film thickness) (Agilent Technologies). Extract of $1 \mu \mathrm{L}$ was injected in split mode with split ratio 100:1 at an injection temperature of $125^{\circ} \mathrm{C}$, oven was initially programmed at $35{ }^{\circ} \mathrm{C}$ (held for $2 \mathrm{mins}$ ) then ramped at $4{ }^{\circ} \mathrm{C} / \mathrm{min}$ to $50{ }^{\circ} \mathrm{C}$ and then $10^{\circ} \mathrm{C} / \mathrm{min}$ to $220^{\circ} \mathrm{C}$, the helium flow rate was set at $1.5 \mathrm{~mL} / \mathrm{min}$, while the mass range was set at $35-260 \mathrm{~m} / \mathrm{z}$ and scan time at $0.6 * 2 \mathrm{sec} /$ scan (Enuneku and Ilegomah, 2015).

\subsubsection{Analysis of PAH}

The stationary phase of separation of the compounds used was an HP-5 capillary column coated with 5\% Phenyl Methyl Siloxane (30m length x $0.32 \mathrm{~mm}$ diameter $\mathrm{x} 0.25 \mu \mathrm{m}$ film thickness) (Agilent Technologies) according to Meador et al. (1995). $1 \mu \mathrm{L}$ of the samples (water, soil, intestine, or parasite tissue) was injected in splitless mode at an injection temperature of $300^{\circ} \mathrm{C}$, at a pressure of $13.74 \mathrm{psi}$ and a total flow of $21.364 \mathrm{~mL} / \mathrm{min}$. Purge flow to split vent was set at $15 \mathrm{~mL} / \mathrm{min}$ at $0.75 \mathrm{~min}$. The oven was initially programmed at $40^{\circ} \mathrm{C}(1 \mathrm{~min})$ then ramped at $12^{\circ} \mathrm{C} / \mathrm{min}$ to $300{ }^{\circ} \mathrm{C}(10 \mathrm{~min})$. FID temperature was $300{ }^{\circ} \mathrm{C}$ with Hydrogen: Airflow at $30 \mathrm{~mL} / \mathrm{min}: 300 \mathrm{~mL} / \mathrm{min}$ while nitrogen was used as makeup gas at a flow of $22 \mathrm{~mL} / \mathrm{min}$. Agilent 7890B gas chromatography coupled to flame ionization detector (GC-FID) was used for the determination of PAH at $254 \mathrm{~nm}$. After calibration, the samples were analyzed and corresponding PAH concentrations were obtained.

\subsection{Determination of biochemical biomarkers}

$0.1 \mathrm{ml}$ of the intestine and parasite tissue homogenate (Tris-HCl buffer, $\mathrm{pH} 7.5$ ) was treated with $2 \mathrm{ml}$ of (1:1:1 ratio)
TBA-TCA-HCI reagent (thiobarbituric acid $0.37 \%, 0.25 \mathrm{~N}$ $\mathrm{HCI}$ and $15 \%$ TCA) and placed in a water bath for $15 \mathrm{~min}$, cooled and centrifuged at room temperature for $10 \mathrm{~min}$ at 3,000rpm. The absorbance of clear supernatant was measured against reference blank at $535 \mathrm{~nm}$.

\subsubsection{Determination of lipid peroxidation}

Malondialdehyde (MDA) was considered an index of lipid peroxidation. It was determined using the methods of Niehaus and Samuelsson (1968), Buege and Aust (1978) which was modified by Jiang et al. (1992). $10 \mathrm{~mL}$ of the supernatant was added to the $2 \mathrm{~mL}$ of $(1: 1: 1$ ratio) TCA-TBA- $\mathrm{HCl}$ reagent (thiobarbituric acid $0.37 \%, 0.24 \mathrm{~N}$ $\mathrm{HCl}$ and $15 \%$ TCA) trichloroacetic acid-thiobarbituric acid-hydrochloric acid reagent boiled at $100 \% \mathrm{C}$ for $15 \mathrm{~min}$ and allowed to cool. Flocculent materials were removed by centrifuging at $3000 \mathrm{rpm}$ for $10 \mathrm{~min}$. The supernatant was removed and then read the absorbance at $532 \mathrm{~nm}$ against a blank. MDA was calculated in the intestine and parasite tissues using the molar extinction coefficient for MDATBA- complex of $1.56 \times 10^{5} \mathrm{M}^{-1} \mathrm{CM}^{-1}$.

$M D A=\frac{A \times V_{T}}{\sum \times V_{s}}$

$\mathrm{A}=$ Absorbance, $\mathrm{V}_{\mathrm{T}}=$ Total volume, $\mathrm{V}_{\mathrm{s}}=$ sample volume, $\Sigma=$ molar extinction.

\subsubsection{Determination of reduced glutathione (GSH)} activity

GSH was determined by the method of Ellman (1959). $10 \%$ TCA was added to the intestine and parasite tissue homogenates and centrifuged at $300 \mathrm{rpm}$ for $20 \mathrm{mins}$. $1.0 \mathrm{~mL}$ of supernatant was treated with $0.5 \mathrm{ml}$ of Ellman's reagent $(19.8 \mathrm{mg}$ of 5,5 '-dithiobisnitro benzoic acid (DTNB) in $100 \mathrm{~mL}$ of $0.1 \%$ sodium nitrate) and $3.0 \mathrm{~mL}$ of phosphate buffer $(0.2 \mathrm{M}, \mathrm{pH} 8.0)$. We then read the absorbance at $412 \mathrm{~nm}$.

\subsubsection{Determination of catalase (CAT) activity}

CAT was assayed calorimetrically at $620 \mathrm{~nm}$ and expressed as moles of hydrogen peroxide $\left(\mathrm{H}_{2} \mathrm{O}_{2}\right)$ consumed/ $\mathrm{min} / \mathrm{mg}$ protein as described by Quinlan et al. (1994). The reaction mixture $(1.5 \mathrm{~mL})$ contained $1.0 \mathrm{~mL}$ of $0.01 \mathrm{M}$ pH 7.0 phosphate buffer, $0.1 \mathrm{~mL}$ of homogenized intestine and parasite samples and $0.4 \mathrm{~mL}$ of $2 \mathrm{M} \mathrm{H}_{2} \mathrm{O}_{2}$. The reaction was discontinued by adding $2.0 \mathrm{~mL}$ of dichromate-acetic acid reagent $(5 \%$ potassium dichromate and glacial acetic acid were mixed in 1:3 ratio).

\subsubsection{Determination of superoxide dismutase (SOD)} activities

SOD activities in the intestine and parasite tissue homogenates were determined using the procedures of Marklund and Marklund (1974) with some modifications. The method relies on the ability of SOD to inhibit the autoxidation of pyrogallol. In $970 \mu \mathrm{L}$ of buffer $(100 \mathrm{mM}$ Tris-HCl, 1 mM EDTA, $\mathrm{pH} 8.2$ ), $10 \mu \mathrm{L}$ of homogenates, and $20 \mu \mathrm{L}$ pyrogallol $13 \mathrm{mM}$ were collected using a micropipette and mixed in a test tube. The assay was 
performed in thermostated cuvettes at $25^{\circ} \mathrm{C}$ and changes of absorption were recorded by a spectrometer (Spectronic 20D) at $480 \mathrm{~nm}$. We defined one unit of SOD activity as the amount of enzyme required to inhibit the auto-oxidation of $50 \%$ of the total pyrogallol in the reaction.

\subsection{Histopathological analysis}

The intestines of fish were placed in bottles containing Bouin's fluid, after which it was decanted and $10 \%$ buffered formalin was added to preserve the intestinal tissue. Random selection was made from the preserved tissues based on infection status. The tissues were routinely dehydrated in an ascending series of alcohol (1\%, 3\%, 5\%, and s7\%) at 30 minutes interval; it was then embedded in molten paraffin wax and allowed to solidify. The blocked tissues were sectioned at 4-5 microns processed and stained with hematoxylin and eosin (H\&E) stains. The stained tissues were washed off in tap water and the over stained ones destined in $1 \%$ alcohol. The tissues were mounted using DPX mutant dehydrated and examined under the microscope (American Optical Corporation, Model 570).

\subsection{Quality assurance/ quality control $(Q A / Q C)$ measures}

The dissecting instruments and sampling containers used were pre-cleaned using $80 \%$ ethanol and sterilized under an autoclave at $120^{\circ} \mathrm{C}$ for $2 \mathrm{~h}$ before use. One surgical blade was used per tissue sample, after when it was discarded safely. To avoid contamination of samples, sterile laboratory gloves, and nose masks were used throughout the experimental session. For quality assurance purposes, analyte grade saline water was screened for microbes and contamination. All readings were taken in triplicate to minimize errors

Appropriate QA/QC measures were taken to ascertain result integrity. Reagent blank determinations were used to correct the instrument readings. Calibration of analytical instruments and readings were taken 5 times, with the mean recorded to minimize possible errors. Standard reference materials SRM 2977 (mussel tissue) was procured from NIST (Gaithersburg, ND, USA). Acetone (Riedel-de Haen, Sezzle, Germany, purity 99.2\%) and CAN (Sigma-Aldrich, Steinheim, Germany, purity $>99 \%$ ) were the solvents used for calibrating and validating obtained results which were obtained using triplicates, spikes, and method blanks for correction of systemic errors. All solutions were prepared gravimetrically using a 220 g semi-micro balance - XP205, with a readability of $0.00001 \mathrm{~g}$ (Merck, Nigeria) and an analytical balance of $1.2 \mathrm{~kg}$ - PR 1203, with a readability of $0.001 \mathrm{~g}$ (Merck, Nigeria). Five (5) $\mathrm{mg}$ of high-purity materials were used for the batch preparation of the candidate certified reference material. The analytical balance XP205 was used to assess the purity of reagents used as prescribed by Guimarães et al. (2014).

\subsection{Statistical analysis}

Descriptive statistics of BTEX concentration in water, sediment, and intestinal tissues, and antioxidant enzymes were presented as mean \pm standard deviation using analysis of variance (ANOVA) and significantly different means were ascertained by post hoc Tukey's HSD test at $\mathrm{P}<0.05$ for all analyses using SPSS 2010 version. Before ANOVA the assumption of normality was verified using the Shapiro-Wilk test.

The percentage parasite prevalence (Saliu et al., 2014) and intensity (Ezewanji et al., 2005) were calculated thus; Percentage Prevalence $=\frac{\text { Number of infected fish }}{\text { Number of fish examined }} \times 100($ Saliu et al., 2014$)$

Parasite intensity $=\frac{\text { Number of collected parasites }}{\text { Number of infected toads }}($ Ezewanji et al., 2005)

The distribution coefficient (Kd) was used to determine the absorption capacity of the parameters into the sediment (Soares and Alleoni, 2006). Values less than 1 were considered insignificant;

$K d=\frac{C s}{C w}$

Where $\mathrm{Cs}=$ concentration of contaminant in the sediment sample, and $\mathrm{CW}$ represents the concentration of contaminant in water.

Biota-sediment accumulation factor (BSAF) which is the concentration of contaminants accumulated from the sediment into the entire body of the fish was calculated as;

$B S A F=\frac{C f}{C s}$

Where Cf represents the concentration of contaminant in the fish and $\mathrm{Cs}$ is the concentration in the sediment sample

The bioaccumulation factor of contaminants from water to the intestine $(\mathrm{BAFi} / \mathrm{w})$ of fish was calculated thus;

$B A F i / w=\frac{C i}{C w}$,

where $\mathrm{Ci}$ represents the concentration of contaminants in the intestine, and $\mathrm{Cw}$ represents the concentration of contaminants in water.

The bioaccumulation factor of contaminants from the intestine into intestinal parasite $(\mathrm{BAF} / \mathrm{l})$ of fish was calculated thus;

$B A F p / i=\frac{C p}{C i}$,

where $\mathrm{Cp}$ represents the concentration of contaminants in the parasite, and $\mathrm{Ci}$ represents the concentration of contaminants in the intestine.

\section{Results}

Most of the physicochemical properties of the lagoon at the three stations were not significantly different (Table 1), except for the dissolved oxygen which was significantly higher at Station 2 and 3 than Station 1, which was higher than the Federal Environmental Protection Limit (FEPA, 2003) limit for dissolved oxygen $(7.5 \mathrm{mg} / \mathrm{L})$.

Comparative analysis between the standard lengths and parasite prevalence in 134 samples of M. electricus (Table 2) 
Table 1. Physicochemical properties in the water from Lekki lagoon presented as Mean \pm SD.

\begin{tabular}{lcccc}
\hline \multicolumn{1}{c}{ PARAMETERS } & Station 1 & Station 2 & Station 3 & FEPA (2003) \\
\hline Temperature $\left({ }^{0} \mathrm{C}\right)$ & $30.46 \pm 1.66$ & $29.63 \pm 3.66$ & $30.2 \pm 3.39$ & - \\
$\mathrm{pH}$ & $4.53 \pm 0.15$ & $4.40 \pm 0.17$ & $4.50 \pm 0.00$ & $6-8$ \\
Dissolved Oxygen $(\mathrm{mg} / \mathrm{L})$ & $\mathbf{1 2 . 6 3} \pm \mathbf{4 . 7 0}$ & $\mathbf{1 9 . 9 0} \pm \mathbf{2 . 0 9 *}$ & $\mathbf{2 1 . 2 6} \pm \mathbf{5 . 7 0 *}$ & 7.5 \\
Total Dissolved Solids $(\mathrm{g} / \mathrm{L})$ & $0.03 \pm 0.05$ & $0.04 \pm 0.06$ & $0.04 \pm 0.06$ & 2000 \\
Conductivity $(\mu \mathrm{S} / \mathrm{cm})$ & $0.07 \pm 0.07$ & $0.09 \pm 0.07$ & $0.05 \pm 0.06$ & 400 \\
Salinity $(\mathrm{ppt})$ & $0.03 \pm 0.05$ & $0.03 \pm 0.05$ & $0.03 \pm 0.05$ & - \\
Turbidity $(\mathrm{NTU})$ & $111.46 \pm 9.53$ & $115.53 \pm 9.88$ & $122.33 \pm 7.79$ & - \\
\hline
\end{tabular}

Emboldened figures are higher than the regulatory limit. Asterisked figures are significantly higher at $\mathrm{p}<0.05$. Sampling size $\mathrm{N}=7$.

Table 2. Prevalence of E. malopteruri in M. electricus relative to standard length (SL) of fish.

\begin{tabular}{cccccc}
\hline SL (cm) & $\begin{array}{c}\text { Number } \\
\text { Examined }\end{array}$ & No. Infected & Prevalence (\%) & $\begin{array}{c}\text { Number of } \\
\text { parasites }\end{array}$ & $\begin{array}{c}\text { Parasite } \\
\text { intensity }\end{array}$ \\
\hline \multicolumn{7}{c}{ MALE } & & & \\
\hline $1.00-4.90$ & 2 & 0 & 0 & 0 & 0 \\
$5.00-9.90$ & 3 & 0 & 0 & 0 & 0 \\
$10.00-14.90$ & 60 & 4 & 6.67 & 12 & 3 \\
$15.00-19.90$ & 34 & 5 & 14.71 & 19 & 3.8 \\
$20.00-24.90$ & 2 & 0 & 0 & 0 & 0 \\
\hline & 0 & 0 & 0 & 0 & 0 \\
\hline $1.00-4.90$ & 0 & 0 & 0 & 0 & 0 \\
$5.00-9.90$ & 20 & 4 & 20 & 14 & 3.5 \\
$10.00-14.90$ & 13 & 0 & 0 & 0 & 0 \\
$15.00-19.90$ & \multicolumn{7}{c}{ FEMALE } & & \\
\hline
\end{tabular}

showed that among the males, SL cohorts of $15.00-19.90 \mathrm{~cm}$ had the highest prevalence of $14.71 \%$, while there was no infection in 1.00-4.90 cm, $5.0-9.90 \mathrm{~cm}$, and $20.0-24.90 \mathrm{~cm}$. On the other hand, among the female's standard length of $10.00-14.90 \mathrm{~cm}$ had the highest prevalence of $20 \%$, while $0 \%$ prevalence was recorded in other female cohorts.

In the male fish, the highest mean intensity of parasites was recorded among standard length cohort of $15.00-$ $19.90 \mathrm{~cm} \mathrm{(3.8),} \mathrm{followed} \mathrm{by} 10.00-14.90 \mathrm{~cm} \mathrm{(3),} \mathrm{while}$ the only cohort in the female with parasite intensity (3.5) was $10.00-14.90 \mathrm{~cm}$.

Similar comparative conducted between weight cohorts and parasite prevalence is presented in Table 3. The order of parasite prevalence among the weight cohorts was $70.00-79.90 \mathrm{~g}$ $(25 \%)>50.00-59.90 \mathrm{~g}(14.29 \%)>20.00-29.90 \mathrm{~g}(13.04 \%)>$ $10.00-19.90 \mathrm{~g}(10 \%)>40.00-49.90 \mathrm{~g}, 30.00-39.90 \mathrm{~g}$ $(8.33 \%)>$ others $(0 \%)$.

Among the females the order was $20.00-29.90 \mathrm{~g}(50.00 \%)>$ $1.00-9.90 \mathrm{~g}(33.33 \%)>50.00-59.90 \mathrm{~g}(25.00 \%)>40.00-49.90 \mathrm{~g}$ $(11.10 \%)>$ others $(0 \%)$. While the combined sexes showed an order of $70.00-79.90 \mathrm{~g}(25.00 \%)>50.00-59.90 \mathrm{~g}(18.18 \%)>$ $20.00-29.90 \mathrm{~g}(16.00 \%)>1.00-19.90 \mathrm{~g}(11.11 \%)>40.00-$ $49.90 \mathrm{~g}(9.52 \%)>10.00-19.90 \mathrm{~g}(8.33 \%)>30.00-39.90 \mathrm{~g}$ $(6.25 \%)>$ others $(0 \%)$.

There was significant adsorption of BTEX, benzene, toluene, ethylbenzene, $\mathrm{m}+\mathrm{p}$-xylene, and o-xylene on to the sediment (Table 4). The intestine of $M$. electricus accumulated significantly high concentration of methyl tertiary-butyl ether (MTBE) from water (12.27), and soil
(9.61). It also accumulated significant concentration of $\mathrm{m}+\mathrm{p}$-xylene from water (1.13), and chlorobenzene (4.5) from sediment. No significant bioaccumulation was recorded in the intestine of $M$. electricus. The parasite also bioaccumulated a significant amount of ethylbenzene (6.96), o-xylene (7.28), $\mathrm{m}+\mathrm{p}$-xylene (8.75), and 1,4-dichlorobenzene (2.40) from the fish host. No significant bioaccumulation of the BTEX compounds was observed in the intestine of the fish.

The concentration profile of MTBE in the entire environmental matrices was intestine $>$ sediment $>$ water. The profile for chlorobenzene was intestine $>$ sediment $>$ water, while that of ethylbenzene was sediment $>$ water $>$ intestine. That of $\mathrm{m}+\mathrm{p}$-xylene was sediment $>$ intestine $>$ water $>$, while that of 1,4-dichlorobenzene was sediment> intestine $>$ water.

A strong correlation occurred among most of the tested environmental media (Table 5), except the distribution coefficient $(\mathrm{Kd})$ which weakly correlated with the concentration of BTEX in the fish intestine (0.14) and biota-sediment accumulation factor BSAF (0.01). High correlation (0.92) between BTEX concentrations in water and sediment suggests that the toxicant concentrations in both specimens are from the same source. Thus explaining the high correlation ( 0.72$)$ between BTEX concentration in water and $\mathrm{Kd}$. A very high positive correlation (0.99) between $\mathrm{BAFi} / \mathrm{w}$ and concentration of BTEX in the intestine of the fish suggests the fish intestine accumulated a significant amount of BTEX from the water. The high 
Table 3. Prevalence of E. malopteruri in M. electricus in relative to the body weight of the fish.

\begin{tabular}{|c|c|c|c|}
\hline Weight (g) & Number Examined & No. Infected & Prevalence (\%) \\
\hline \multicolumn{4}{|c|}{ MALE } \\
\hline $1.00-9.90$ & 6 & 0 & 0 \\
\hline $10.00-19.90$ & 20 & 2 & 10 \\
\hline $20.00-29.90$ & 23 & 3 & 13.04 \\
\hline $30.00-39.90$ & 12 & 1 & 8.33 \\
\hline $40.00-49.90$ & 12 & 1 & 8.33 \\
\hline $50.00-59.90$ & 7 & 1 & 14.29 \\
\hline $60.00-69.90$ & 6 & 0 & 0 \\
\hline $70.00-79.90$ & 4 & 1 & 25 \\
\hline $80.00-89.90$ & 4 & 0 & 0 \\
\hline $90.00-99.90$ & 3 & 0 & 0 \\
\hline $100.00-109.90$ & 0 & 0 & 0 \\
\hline $110.00-119.90$ & 2 & 0 & 0 \\
\hline $120.00-129.90$ & 1 & 0 & 0 \\
\hline $130.00-139.90$ & 0 & 0 & 0 \\
\hline $140.00-149.90$ & 0 & 0 & 0 \\
\hline $150.00-159.90$ & 1 & 0 & 0 \\
\hline \multicolumn{4}{|c|}{ FEMALE } \\
\hline $1.00-9.90$ & 3 & 1 & 33.33 \\
\hline $10.00-19.90$ & 4 & 0 & 0 \\
\hline $20.00-29.90$ & 2 & 1 & 50 \\
\hline $30.00-39.90$ & 4 & 0 & 0 \\
\hline $40.00-49.90$ & 9 & 1 & 11.1 \\
\hline $50.00-59.90$ & 4 & 1 & 25 \\
\hline $60.00-69.90$ & 5 & 0 & 0 \\
\hline $70.00-79.90$ & 0 & 0 & 0 \\
\hline $80.00-89.90$ & 2 & 0 & 0 \\
\hline
\end{tabular}

Table 4. Bioaccumulation indices of BTEX in water $\left(\mathrm{mg} \mathrm{L}^{-1}\right)$, sediment $\left(\mathrm{mg} \mathrm{kg}^{-1}\right)$, M. electricus $\left(\mathrm{mg} \mathrm{kg}^{-1}\right)$ and the depurative capacity of its enteric parasite, Electrotaenia malopteruri.

\begin{tabular}{ccccccccc}
\hline BTEX & Water & Sediment & Kd & Intestine & BAFi/w & BSAF & Parasite & BAFp/i \\
\hline MTBE & $19.73 \pm 2.56$ & $25.17 \pm 3.02$ & $\mathbf{1 . 2 8}$ & $241.99 \pm 9.69$ & $\mathbf{1 2 . 2 7}$ & $\mathbf{9 . 6 1}$ & $\mathrm{BD}$ & 0.00 \\
Benzene & $9.51 \pm 1.04$ & $23.63 \pm 1.41$ & $\mathbf{2 . 4 8}$ & $4.33 \pm 1.68$ & 0.46 & 0.18 & $\mathrm{BD}$ & 0.00 \\
Toluene & $10.86 \pm 0.34$ & $14.90 \pm 1.03$ & $\mathbf{1 . 3 7}$ & $8.13 \pm 2.92$ & 0.75 & 0.54 & 0.00 & 0.00 \\
CB & $\mathrm{BD}$ & $4.35 \pm 0.31$ & - & $19.58 \pm 1.14$ & - & $\mathbf{4 . 5 0}$ & 1120 & $\mathbf{5 7 . 2 4}$ \\
EB & $7.02 \pm 0.07$ & $9.04 \pm 2.01$ & $\mathbf{1 . 2 9}$ & $6.65 \pm 2.66$ & 0.95 & 0.74 & $\mathbf{4 6 . 2 9}$ & $\mathbf{6 . 9 6}$ \\
m+p-xylene & $7.34 \pm 0.41$ & $8.75 \pm 0.23$ & $\mathbf{1 . 1 9}$ & $8.27 \pm 1.61$ & $\mathbf{1 . 1 3}$ & 0.95 & $\mathbf{7 2 . 3 6}$ & $\mathbf{8 . 7 5}$ \\
o-xylene & $7.92 \pm 0.34$ & $14.15 \pm 1.02$ & $\mathbf{1 . 7 9}$ & $6.45 \pm 0.79$ & 0.81 & 0.46 & $\mathbf{4 6 . 9 6}$ & $\mathbf{7 . 2 8}$ \\
$1,3-\mathrm{DCB}$ & $\mathrm{BD}$ & $\mathrm{BD}$ & - & $0.00 \pm 0.00$ & - & - & 0.00 & 0.00 \\
$1,4-\mathrm{DCB}$ & $\mathrm{BD}$ & $1.43 \pm 0.10$ & - & $0.16 \pm 0.34$ & - & 0.11 & - & $\mathbf{2 . 4 0}$ \\
$1,2-\mathrm{DCB}$ & $\mathrm{BD}$ & $\mathrm{BD}$ & - & $0.42 \pm 1.02$ & - & - & - & 0.00 \\
\hline
\end{tabular}

$\mathrm{MTBE}=$ methyl tertiary-butyl ether, $\mathrm{CB}=$ chlorobenzene, $\mathrm{EB}=$ ethylbenzene, $\mathrm{DCB}=$ dichlorobenzene, $\mathrm{BD}=$ below detection, $\mathrm{Kd}=$ adsorption, $\mathrm{BAFi} / \mathrm{w}=$ bioaccumulation factor from water to intestine, $\mathrm{BSAF}=$ biota-sediment accumulation factor, $\mathrm{BAFp} / \mathrm{i}=$ bioaccumulation factor from intestine to parasite, sample size $(\mathrm{N})=134$. Adsorption and bioaccumulation $>$ or $=1$ is significant

Table 5. Correlations among environmental media and their affinities for BTEX.

\begin{tabular}{cccccccc}
\hline & Water & Sediment & $\boldsymbol{K d}$ & Intestine & $\boldsymbol{B A F i} / \boldsymbol{w}$ & $\boldsymbol{B S A F}$ & $\boldsymbol{B A F} \boldsymbol{i}$ \\
\hline Water & 1 & & & & & & \\
Sediment & $\mathbf{0 . 9 1 6 1 3 8}$ & 1 & & & & & \\
Kd & $\mathbf{0 . 7 1 7 8 4}$ & $\mathbf{0 . 8 5 8 1 8 7}$ & 1 & & & & \\
Intestine & $\mathbf{0 . 7 4 0 1 9 5}$ & $\mathbf{0 . 5 8 3 2 1 7}$ & 0.139198 & 1 & & \\
BAFi/w & $\mathbf{0 . 7 9 6 2 0 5}$ & $\mathbf{0 . 6 2 4 1 3 5}$ & 0.216145 & $\mathbf{0 . 9 9 1 9 2 1}$ & 1 & & \\
BSAF & $\mathbf{0 . 5 9 4 9 7 2}$ & 0.477785 & 0.013425 & $\mathbf{0 . 9 2 9 5 1}$ & $\mathbf{0 . 8 8 7 6 8 5}$ & 1 & \\
BAFp/i & -0.33803 & -0.23542 & -0.32192 & $\mathbf{- 0 . 6 9 7 9 3}$ & -0.18977 & 0.274005 & 1 \\
\hline
\end{tabular}

$\mathrm{Kd}=$ distribution coefficient, $\mathrm{BAFi} / \mathrm{w}=$ bioaccumulation factor from water to intestine, $\mathrm{BSAF}=$ biota-sediment accumulation factor, $\mathrm{BAFp} / \mathrm{i}=$ bioaccumulation factor from intestine to parasite 
positive correlation between the biota-sediment accumulation factor (BSAF), characterized by the accumulation of toxicants from the sediment into the intestine of the fish also suggests that a significant amount of BTEX was accumulated from the sediment into the intestine. There was a significant negative correlation between BAFp/i and the concentration of BTEX in the intestine of the fish.

Fluorene, phenanthrene, and chrysene were significantly adsorbed unto the sediment (Table 6). Highly significant bioaccumulation of chlorobenzene (57.24) from the intestine of M. electricus was detected in the Parasite, E. malapteruri. The intestine of $M$. electricus bioaccumulated significant amounts of naphthalene (1.15), acenaphthene (1.22), fluorine (7.26), anthracene (4.04), phenanthrene (2.43), and benzo(c)phenanthrene. Very high bioaccumulation of fluoranthene (175.32), and chrysene (126.36) were also recorded in the intestine of the fish. The fish also significantly accumulated acenaphthylene (1.10), acenaphthene (2.58), fluorene (4.64), anthracene (4.85), phenanthrene (1.42), and benzo(c)phenanthrene (13) from the sediment. Very high fluorene (730.50), pyrene $(1,032.00)$, and chrysene (108.90) were highly accumulated from the sediment.

The parasite only accumulated significant amounts of fluorene (1.09), and anthracene (1.29) from the intestine of the host, $M$. electricus.

$\mathrm{Kd}$ had a strong correlation (0.603) with the PAH concentration in the sediment, suggesting that the bottom sediment must have received a significant amount of PAH from the overlying water column (Table 7). A significant correlation (0.685) occurred between the intestine PAH concentrations and BSAF further indicated that the PAH in the sediment bioaccumulated significantly into the intestine. The highly significant positive correlation between the concentration of $\mathrm{PAH}$ in the fish intestine and the $\mathrm{BAFi} / \mathrm{w}$ indicates that the toxicant was also accumulated from the ambient water. There was no significant correlation between BAFp/i and the concentration of PAH in the intestine of the fish.

The concentration of GSH and SOD were significantly lower in the intestine of uninfected fish than in the intestine of the infected fish. There was no significant difference detected in the CAT level among the infected, uninfected, and the enteric parasite, E. malopteruri (Table 8). The concentration of MDA in the tested media was in the order of uninfected fish $>$ infected fish $>$ parasite $(p<0.05)$.

Histopathological analysis of $M$. electricus intestine was conducted based on the length cohorts in which we grouped the fishes. Length-based histopathological alterations occurred among the fish length cohorts (Figures 2-6). Photomicrographs of intestinal tissue among M. electricus of length cohort $1.00-4.90 \mathrm{~cm}$ showed normal villi structure, normal mucosa, submucosa, and muscularis in (Figure 2). Among length cohorts of $5.00-9.90 \mathrm{~cm}$, photomicrographs of intestinal tissue showed normal villi structure, normal

Table 6. Bioaccumulation indices of PAH congeners in water $\left(\mathrm{mg} \mathrm{L}^{-1}\right)$, sediment $\left(\mathrm{mg} \mathrm{kg}^{-1}\right)$, M. electricus $\left(\mathrm{mg} \mathrm{kg}^{-1}\right)$ and the depurative capacity of its enteric parasite, Electrotaenia malopteruri.

\begin{tabular}{lcccccccc}
\hline \multicolumn{1}{c}{ PAH congeners } & Water & Sediment & Kd & Intestine & BAFi/w & BSAF & Parasite & BAFp/i \\
\hline Naphthalene $^{\mathrm{a}}$ & $0.20 \pm 0.02$ & $0.41 \pm 0.01$ & 0.21 & $0.23 \pm 0.01$ & $\mathbf{1 . 1 5}$ & 0.56 & $\mathrm{BD}$ & - \\
Acenaphthylene $^{\mathrm{a}}$ & $0.29 \pm 0.01$ & $0.22 \pm 0.00$ & 0.76 & $0.24 \pm 1.68$ & 0.83 & $\mathbf{1 . 1 0}$ & $\mathrm{BD}$ & - \\
Acenaphthene $^{\mathrm{a}}$ & $0.51 \pm 0.01$ & $0.24 \pm 0.01$ & 0.52 & $0.62 \pm 0.02$ & $\mathbf{1 . 2 2}$ & $\mathbf{2 . 5 8}$ & 0.56 & 0.91 \\
Fluorene $^{\mathrm{a}}$ & $0.23 \pm 0.01$ & $0.36 \pm 0.02$ & $\mathbf{1 . 5 7}$ & $1.67 \pm 0.02$ & $\mathbf{7 . 2 6}$ & $\mathbf{4 . 6 4}$ & 1.82 & $\mathbf{1 . 0 9}$ \\
Anthracene $^{\mathrm{b}}$ & $0.24 \pm 0.03$ & $0.20 \pm 0.01$ & 0.25 & $0.97 \pm 0.01$ & $\mathbf{4 . 0 4}$ & $\mathbf{4 . 8 5}$ & 1.25 & $\mathbf{1 . 2 9}$ \\
Phenanthrene $^{\mathrm{a}}$ & $0.21 \pm 0.01$ & $0.36 \pm 0.01$ & $\mathbf{1 . 7 1}$ & $0.51 \pm 0.00$ & $\mathbf{2 . 4 3}$ & $\mathbf{1 . 4 2}$ & 0.24 & 0.48 \\
Fluoranthene $^{\mathrm{b}}$ & $0.25 \pm 0.01$ & $0.06 \pm 0.01$ & 0.24 & $43.83 \pm 2.92$ & $\mathbf{1 7 5 . 3 2}$ & $\mathbf{7 3 0 . 5}$ & 29.80 & 0.68 \\
Pyrene $^{\mathrm{b}}$ & $0.00 \pm 0.00$ & $0.01 \pm 0.00$ & - & $10.32 \pm 1.07$ & - & $\mathbf{1 0 3 2}$ & 5.99 & 0.58 \\
Benzo(c)phenanthrene $^{\mathrm{b}}$ & $0.05 \pm 0.01$ & $0.02 \pm 0.00$ & 0.40 & $0.26 \pm 0.34$ & $\mathbf{5 . 2}$ & $\mathbf{1 3}$ & 0.10 & 0.39 \\
Chrysene $^{\mathrm{b}}$ & $0.25 \pm 0.01$ & $0.29 \pm 0.01$ & $\mathbf{1 . 1 3}$ & $31.59 \pm 1.02$ & $\mathbf{1 2 6 . 3 6}$ & $\mathbf{1 0 8 . 9}$ & 16.74 & 0.53 \\
\hline
\end{tabular}

${ }^{2}$ 2-3 rings, ${ }^{b} 4-6$ rings, $\mathrm{BD}=$ below detection, $\mathrm{Kd}=$ adsorption coefficient, $\mathrm{BAFi} / \mathrm{w}=$ bioaccumulation factor from water to intestine, $\mathrm{BSAF}=$ biota-sediment accumulation factor, $\mathrm{BAF} / \mathrm{i}=$ bioaccumulation factor from intestine to parasite, sample size $(\mathrm{N})=134$. Adsorption and bioaccumulation $>$ or $=1$ is significant.

Table 7. Correlation s among environmental media and their affinities for PAH.

\begin{tabular}{|c|c|c|c|c|c|c|c|}
\hline & Water & Sediment & $K d$ & Intestine & $B A F i / w$ & $B S A F$ & $B A F p / i$ \\
\hline Water & 1 & & & & & & \\
\hline Sediment & 0.436875 & 1 & & & & & \\
\hline $\mathrm{Kd}$ & 0.200689 & 0.603021 & 1 & & & & \\
\hline Intestine & -0.04662 & -0.47195 & -0.31221 & 1 & & & \\
\hline $\mathrm{BAFi} / \mathrm{w}$ & 0.073283 & -0.36269 & -0.21696 & 0.970326 & 1 & & \\
\hline BSAF & -0.45145 & 0.65836 & -0.48277 & 0.685028 & 0.48989 & 1 & \\
\hline BAFp/i & 0.235931 & -0.02666 & 0.108877 & -0.26679 & 0.086194 & 0.025795 & 1 \\
\hline
\end{tabular}

$\mathrm{Kd}=$ distribution coefficient, $\mathrm{BAFi} / \mathrm{w}=$ bioaccumulation factor from water to intestine, $\mathrm{BSAF}=$ biota-sediment accumulation factor, $\mathrm{BAFp} / \mathrm{i}=$ bioaccumulation factor from intestine to parasite. Emboldened figures are significant. 
Table 8. Antioxidant activities in the intestine and parasite of M. electricus.

\begin{tabular}{cccc}
\hline $\begin{array}{c}\text { Biochemical parameters } \\
(\boldsymbol{\mu m o l} / \mathbf{m g} \text { prot. })\end{array}$ & Infected fish & Uninfected fish & Parasite \\
\hline GSH & $6.11 \pm 1.82^{\mathrm{a}}$ & $2.62 \pm 1.97^{\mathrm{b}}$ & $8.81 \pm 1.58^{\mathrm{a}}$ \\
& $(4.09-8.03)$ & $(1.35-3.92)$ & $(6.61-10.70)$ \\
SOD & $125.11 \pm 7.05^{\mathrm{a}}$ & $98.79 \pm 4.15^{\mathrm{b}}$ & $126.25 \pm 4.97^{\mathrm{b}}$ \\
& $(116.08-132.77)$ & $(73.81-124.05)$ & $(121.39-134.29)$ \\
CAT & $482.60 \pm 75.06$ & $547.22 \pm 92.60$ & $478.70 \pm 17.42$ \\
& $(258.58-665.09)$ & $(417.16-653.85)$ & $(284.62-689.94)$ \\
MDA & $5.95 \pm 2.16^{\mathrm{c}}$ & $8.76 \pm 0.36^{\mathrm{a}}$ & $6.46 \pm 0.81^{\mathrm{b}}$ \\
& $(3.56-9.23)$ & $(1.40-4.31)$ & $(4.52-6.52)$ \\
\hline
\end{tabular}

Numbers with different superscripts indicate significant difference $(\mathrm{p}<0.05)$
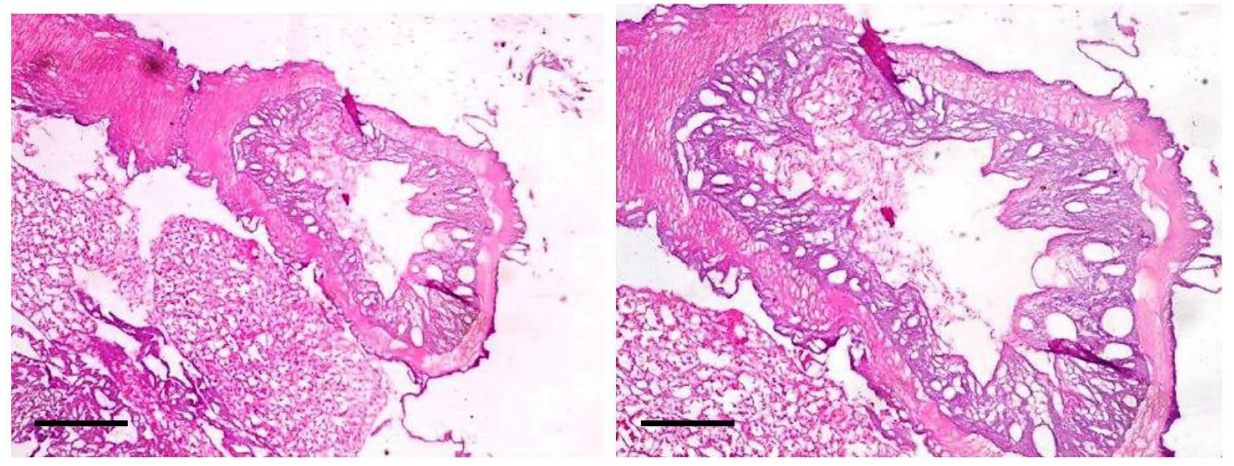

Figure 2. Length cohort $1.00-4.90 \mathrm{~cm}$. Photomicrographs of intestinal tissue show normal villi structure, normal mucosa, mucosa and muscularis. Bar $=250$ and $100 \mu \mathrm{m}$ respectively.

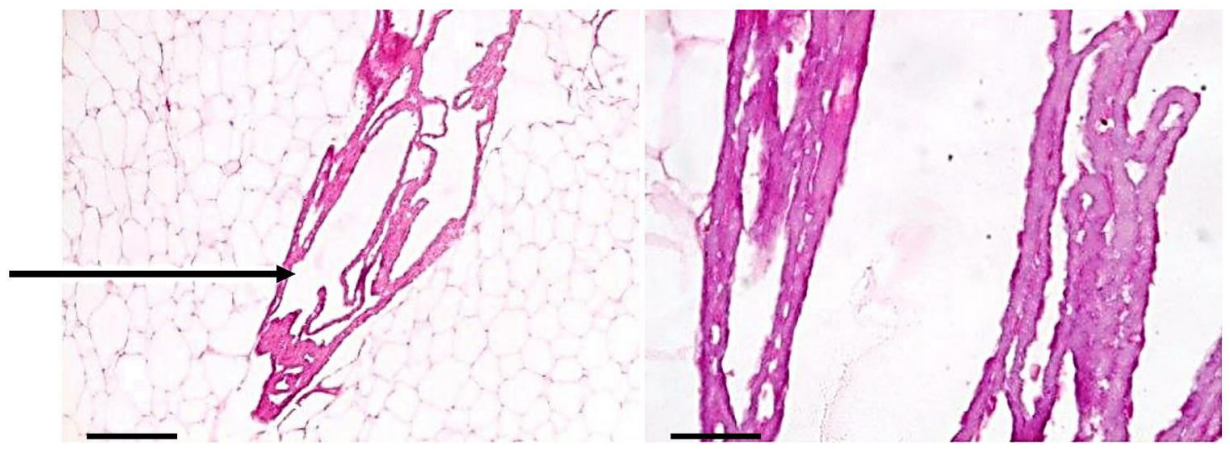

Figure 3. Length cohort $5.00-9.90 \mathrm{~cm}$. Photomicrographs of intestinal tissue show normal villi structure, normal mucosa, submucosa and muscularis although there is mild presence of trophozoites in the lumen (black arrow). Bar= 250 and $100 \mu \mathrm{m}$ respectively.

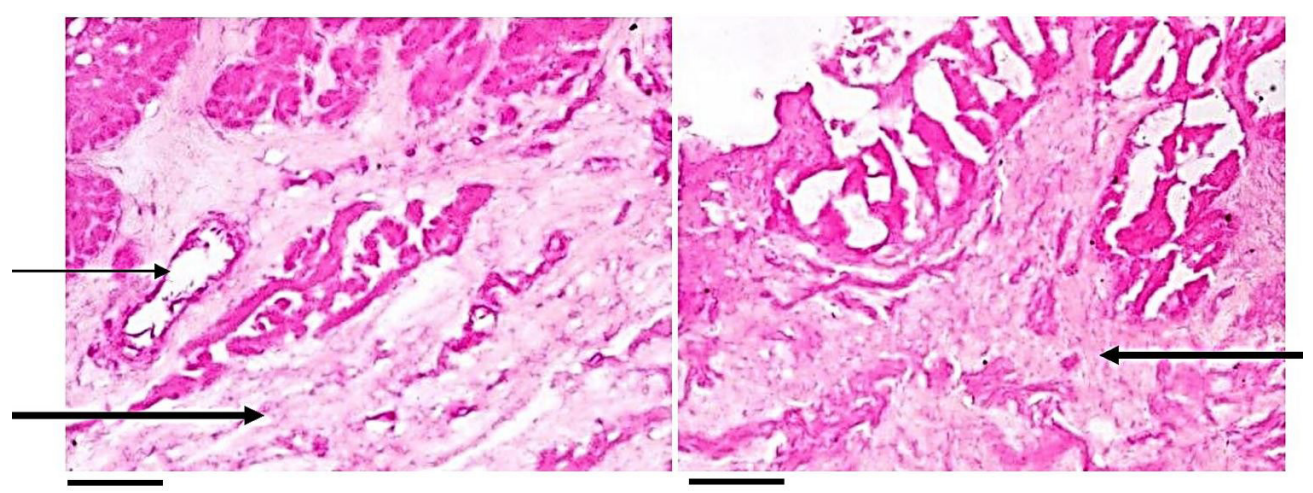

Figure 4. Length cohort $10.00-14.90 \mathrm{~cm}$. Photomicrographs of intestinal tissue showed moderate edema (black arrow) and very mild angiogenesis (thin arrow). Bar $=25 \mu \mathrm{m}$. 


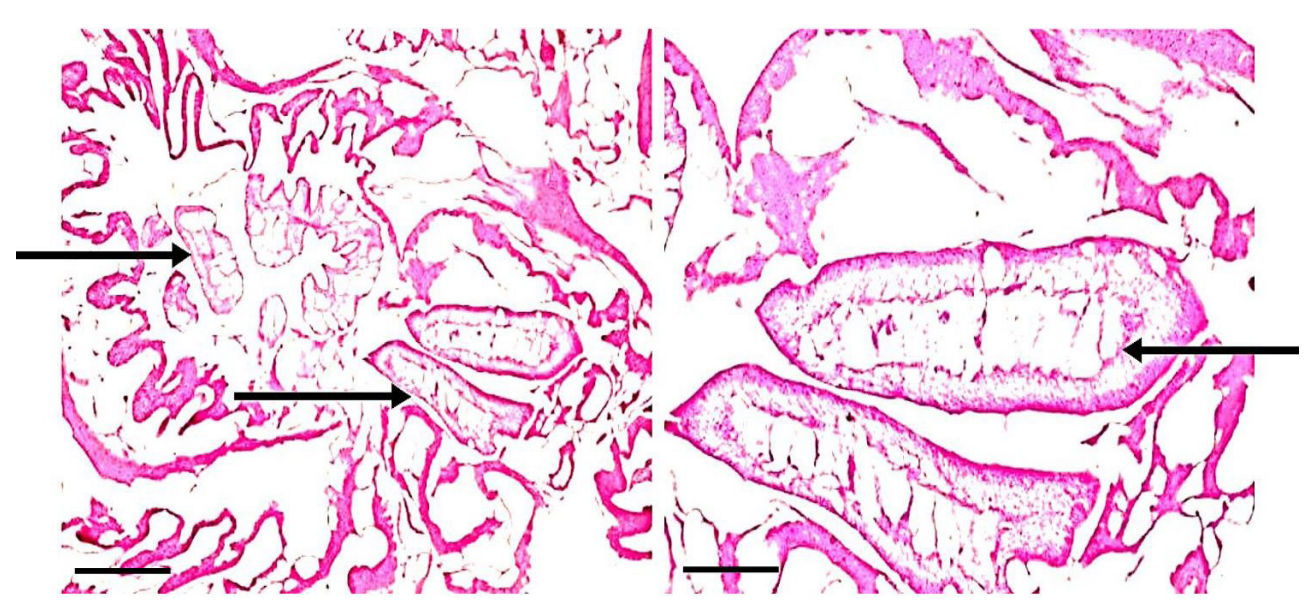

Figure 5. Length cohort $15.00-19.90 \mathrm{~cm}$. Photomicrographs of intestinal tissue show total loss of villi in the lumen (black arrow). Bar $=250$ and $100 \mu \mathrm{m}$ respectively.

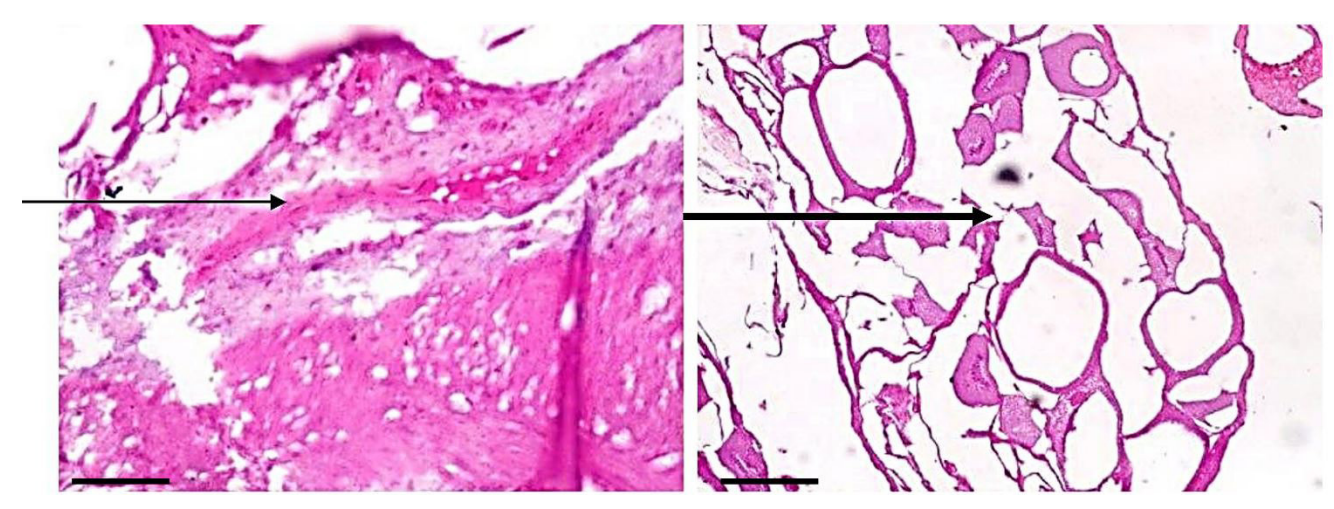

Figure 6. Length cohort $20.00-24.90 \mathrm{~cm}$. Photomicrographs of intestinal tissue show mild angiogenesis with vascular congestion (thin arrow) and a focal area of total loss of villi and abundant presence of stony detritus. Bar $=25 \mathrm{and} 250 \mu \mathrm{m}$ respectively.

mucosa, submucosa, and muscularis although there is the mild presence of trophozoites in the lumen indicated with a black arrow in (Figure 3). Intestinal tissue of length cohort $10.00-14.90 \mathrm{~cm}$ showed moderate edema (black arrow) and very mild angiogenesis indicated with a thin arrow (Figure 4). M. electricus of cohorts $15.00-$ $19.90 \mathrm{~cm}$ showed total loss of villi in the lumen (black arrow) as seen in Figure 5, while Figure 6 depicts intestinal tissue of length cohort $20.00-24.90 \mathrm{~cm}$ showing mild angiogenesis characterized by the growth of blood vessels from the existing vasculature (Adair and Montani, 2010), with vascular congestion indicated by a thin arrow and a focal area of a total loss of villi and abundant presence of stony detritus.

\section{Discussions}

A fish may get infected by ingesting infected copepods. Differences in the incidence of infection between the female and male fish could be due to the physiological state of the females, possibly as a result of immunosuppression, characteristic of gravid females (Fessler, 2002). Relatively higher veracity in males particularly during the competition for food may increase the frequency of contact with the parasites, thereby increasing the chances of infection (Emere, 2000). Current observation is consistent with the reports of Anosike et al. (1992) and Omeji (2013) who observed more parasite infestation in male fish than the female. The observation is however at variance with that of (Emere and Egbe, 2006) and Dankishiya et al. (2013) who reported higher intensity of helminth parasites in the gastrointestinal tract of female wild African sharp tooth catfish (Clarias gariepinus) in Gwagwalada of Federal Capital Territory, Nigeria than the male counterparts.

Although physicochemical properties of the water samples analyzed indicated no serious ecological perturbation, except high oxygen concentrations at Stations 2 and 3, further investigations however showed higher concentrations of BTEX and PAH congeners in the sediment medium than in the water. This can be attributable to the repository nature of the bottom sediment in conjunction with the hydrophobic nature of the contaminants. The time factor plays a significant role in the sink of the toxicants. 
Significant BSAF of methyl tertiary-butyl ether (MTBE) and chlorobenzene (CB) despite the insignificant adsorptions of the toxicants to the sediment implicates the pelagic nature of the fish. Constant contact of the fish with the sediment may result in significant accumulation of the compounds from the sediment over an extended period regardless of the low concentration recorded in the sediment. MTBE is a flammable, colorless liquid with high solubility in water. It is part of a group of chemicals known as fuel oxygenates. Oxygenates do not occur naturally in gasoline. They are added to increase gasoline's oxygen content. Laboratory studies have shown that MTBE exposure may elicit testicular and lymphohematopoietic cancers (Belpoggi et al., 1995; IARC, 1999).

The significant negative correlation between BAFp/i and the concentration of BTEX in the intestine of the fish indicates the parasites significantly sequestered the toxicant's burden from the fish. This contamination attenuation potential of E. malopteruri was supported by the marked parasiteintestine bioaccumulation factor (BAFp/i) of some BTEX components analyzed. Although the parasites were generally of low intensity in the fish, they however exhibited some ability to sequester chlorobenzene, ethylbenzene, o-xylene, $\mathrm{m}+\mathrm{p}$-xylene, and 1,4-dichlorobenzene from the intestine of the fish. Conversely, they showed a poor depurative capacity for PAH in the fish, with no promising depurative capacity even at higher levels of parasite intensity, with exceptions in fluorene, and anthracene on which significant bioaccumulation of 1.09 and 1.29 respectively was recorded.

The fish accumulated most of the PAH congener (particularly fluoranthene, pyrene, and chrysene) in the intestine higher than the rate it accumulated BTEX compounds. Bioaccumulation of PAH congeners in the fish intestine which was accompanied by low bioaccumulation in the parasite indicates the susceptibility of the fish to toxicity impacts of PAH. Of most significance were fluoranthene and chrysene which were highly bioaccumulated in the intestine of the fish but not accumulated in the parasite. Contrary to BTEX, a higher level of PAH in the fish and lower sequestration potentials exhibited by the parasite is attributable to higher hydrophobicity of the latter. Furthermore, the fish M. electricus contains higher lipids thus is more receptive to $\mathrm{PAH}$ than the parasite E. malopteruri.

Higher oxidative stress in the uninfected fish is characterized by the significantly lower concentrations of GSH and SOD in the intestine of M. electricus than the concentration in the infected fish and the enteric parasite shows the uninfected fish were more susceptibility to the toxicants. Higher susceptibility of uninfected fish to the xenobiotics than the infected can be attributed to the depurative functions of the parasite. This observation is consistent with the observation of Vijayavel et al. (2004). SOD is the first enzyme to deal with oxygen radicals (Viarengo, 1989; Vijayavel et al., 2004) by accelerating the dismutation of superoxide $\left(\mathrm{O}^{2-}\right)$ to $\mathrm{H}_{2} \mathrm{O}_{2}$ which damages the membrane and biological structures. Increased intracellular reactive oxygen species (ROS) activities are likely to be associated with PAH toxicity which may have led to decreased concentration of SOD observed in this study. Though superoxide dismutase (SOD) is involved in the protection of biological systems from the actions of free radicals and may be overwhelmed in the event of an excessive toxic onslaught, resulting in oxidative stress, a condition that may be characterized by its eventual inhibition.

Catalase (CAT) was moderately high in the intestinal tissue, with no significant difference between intestine and parasite tissues. Catalase is involved in the decomposition of hydrogen peroxide to water and oxygen. It is very important in protecting the cell from oxidative damage by reactive oxygen species (ROS). Results suggest the toxicants under investigation were not decomposed by the fish or its parasite.

The assessment of MDA which is the by-product of oxidative damage to the phospholipids of cell membranes indicates considerable cellular damage. Lipid peroxidation damage is one of the first indicators of damage to cells by toxicants and represents a key biomarker of oxidative stress (Cini et al., 1994). Glutathione (GSH) is the cofactor of many enzymes catalyzing the detoxification and excretion of many toxic compounds. It is a vital antioxidant agent involved in the protection of cell membranes from lipid peroxidation by scavenging oxygen radicals yielding glutathione disulfide. Glutathione is also the cofactor of a group of enzymes involved in catalyzing the detoxification and excretion of several toxic compounds. Glutathione concentration in the intestine was significantly lower than the concentrations of infected fish. Current observation corresponds with a decrease in SOD, CAT, and GST in conjunction with an increase in MDA observed in the gill of Clarias gariepinus exposed to aromatic hydrocarbons (Otitoloju and Olagoke, 2011). The oxidative stress and histopathological analysis of M. electricus corroborate the toxicological effects of PAH.

Histopathological biomarkers are useful tools in the determination of aquatic ecotoxicological impacts (OliveiraRibeiro et al., 2006). The present study revealed significant alterations in the intestinal tissues of $M$. electricus with increasing length. This is attributable to an increase in appetite (characterized by increased feeding rate) in fish with greater lengths. The histopathological alterations can be partly attributed to the toxicity of methyl tertiarybutyl ether and all screened PAH congeners except acenaphthylene and pyrene which were not accumulated in the intestine. Fluorine and anthracene may also be exempted from the culprits that wreaked havoc on the intestinal tissues of the lengthier fishes as they were depurated from by E. malopteruri from the intestine of the host fish. Histopathological alterations observed in the intestinal tissues are attributable to outcomes of the interactions between the xenobiotics and the oxidative defense system of the fish. Lipid peroxidation damage is one of the foremost damages to cell components that could be inflicted by PAH and BTEX.

No observable alteration was observed among the shortest cohorts, while muscularis mainly characterized the alterations observed among length cohorts $5.00-9.90 \mathrm{~cm}$. 
Muscularis was earlier reported by Kaoud et al. (2011) in the intestinal lumen of $M$. electricus exposed to cadmium. The edema observed among fish cohorts $10.00-14.90 \mathrm{~cm}$ may have been caused by the absorption of fluoranthene and chrysene (Hanna et al., 2005), as they were greatly accumulated from the water and sediment. Epithelial degeneration, inflammatory cell infiltration, and edema have also been observed in the intestine of tilapia exposed to carbofuran for 8 weeks (Soufy et al., 2007). Most varieties of histopathological alterations were observed in the intestine of the lengthiest fish cohorts $(20.00-$ $24.90 \mathrm{~cm}$ ). These include mild angiogenesis (Saliu et al., 2014) with vascular congestion, a focal area of a total loss of villi, and predominant stony detritus. This suggests length-dependent susceptibility.

Results suggest that lengthier and uninfected M. electricus were more susceptible to PAH in Lekki lagoon than the shorter and infected ones. This is possibly due to the relatively smaller surface area which is more easily sequestered by a given number of parasites, compared to the larger fish cohorts.

\section{Conclusion}

The study demonstrated a promising tendency of the enteric parasite, E. malopteruri to depurate chlorobenzene, ethylbenzene, o-xylene, $\mathrm{m}+\mathrm{p}$-xylene, and 1,4-dichlorobenzene from the intestine of its host fish, $M$. electricus, while PAH congeners were poorly mediated by the parasite. The study has presented a useful baseline data in biomonitoring studies.

Regular monitoring and assessment of Lekki lagoon are recommended for effective abatement of oil impacts within the vicinity of the water body to safeguard human health and integrity of the aquatic habitat.

\section{References}

ADAIR, T.H. and MONTANI, J.P., 2010 [viewed 18 April 2020]. Angiogenesis [online]. San Rafael, CA: Morgan and Claypool Life Sciences. Overview of Angiogenesis. Available from: https:// www.ncbi.nlm.nih.gov/books/NBK53238/

ADEYEMI, D., UKPO, G., ANYAKORA, C. and UYIMADU, J.P., 2009. Polychlorinated biphenyl in fish samples from Lagos lagoon, Nigeria. African Journal of Biotechnology, vol. 8, no. 12, pp. 2811-2815.

AKINSANYA, B., ADEBUSAYO, S.A., ALINSON, T., and UKWA, U.D., 2018. Bioaccumulation of polycyclic hydrocarbons, hitopathological alterations, and parasite-fauna in bentho- pelagic host from Snake Island, Lagos, Nigeria. The Journal of Basic and Applied Zoology, vol. 79, no. 40.

AKINSANYA, B., UKWA, U.D. and HASSAN, A.A., 2014. Effect of Host Condition on intestinal parasite load and prevalence in Malapterurus electricus, Gmelin 1789, (Siluriformes: Malapteridae) In Lekki Lagoon, Lagos, Nigeria. Nigeria Journal of Parasitology, vol. 35 , pp. $59-64$

AKINSANYA, M.A., GOH, J.K., LIM, S.P. and TING, A.S, 2015. Metagenomics study of endophytic bacteria in Aloevera using next-generation technology. Genomics Data, vol. 6, pp. 159-163. http://dx.doi.org/10.1016/j.gdata.2015.09.004. PMid:26697361.
AKPOBORIE, I.A., EMOYAN, O.O., ASAGBA, S.O. and BALOGUN, A.Y., 2008. Aromatics in private water supplies in Warri, Delta State, Nigeria. Scientia Africa, vol. 1, no. 7, pp. 74-80.

ALANI, R., DROUILLARD, K., OLAYINKA, K. and ALO, B., 2012. Bioaccumulation of polycyclic aromatic hydrocarbons in fish and invertebrates of Lagos lagoon, Nigeria. Journal of Emerging Trends in Engineering and Applied Sciences, vol. 3, no. 2, pp. 287-296.

ANOSIKE, J.C., OMOREGIE, E., OFOJEKWU, P.C. and NWEKE, I.E., 1992. A survey of helminth parasites of Clarias gariepinus in plateau State. Nigerian Journal of Aquatic Sciences, vol. 7, pp. 39-43.

ANYAKORA, C.A., OGBECHE, OGBECHE, K.A., UNYIMADU, J., OLAYINKA, K., ALANI, R., and ALAO, B., 2004. Determination of polynuclear aromatic hydrocarbons in water samples of the Lagos lagoon. Nigerian Journal Pharmacy, vol. 35, pp. 35-39.

AZQUETA, A., SHAPOSHNIKOV, S. and COLLINS, A.R, 2009. DNA oxidation: investigating its keyrole in environmental mutagenesis with the comet assay. Journal of Mutation Research, vol. 674, no. 1-2, pp. 101-108. http://dx.doi.org/10.1016/j. mrgentox.2008.10.013. PMid:19041417.

BELPOGGI, F., SOFFRITTI, M. and MALTONI, C., 1995. Methyl-Tertiary-Butyl Ether (MTBE) - A gasoline additive - causes testicular and lympho-haematopoietic cancers in rats. Toxicology and Industrial Health, vol. 11, no. 2, pp. 119-149. http://dx.doi.org/10.1177/074823379501100202. PMid:7491630.

BOSCH, M., MANNINO, M.A., PRENDERGAST, A.L., O'CONNELL, T.C., DEMARCHI, B., TAYLOR, S.M., NIVEN, L., VAN DER PLICHT, J.J., and HUBLIN, J., 2015. Reply to Douka et al.: critical evaluation of the Ksa\$r Akil chronologies. Proceedings of the National Academy of Sciences of the United States of America, vol. 112, no. 51, pp. 35

BRUNO, D.W., NOWAK, B. and ELLIOTT, D.G., 2006. Guide to the identification of fish protozoan and metazoan parasites in stained tissue sections. Diseases of Aquatic Organisms, vol. 70, no. 1-2, pp. 1-36. http://dx.doi.org/10.3354/dao070001. PMid:16875388.

BUEGE, J.A. and AUST, S., 1978. Microsomal Lipid Peroxidation. Methods in Enzymology, vol. 52, pp. 302-310. http://dx.doi. org/10.1016/S0076-6879(78)52032-6. PMid:672633.

CINI, M., FARIELLO, R.G., BIANCHETTI, A. and MORETTI, A., 1994. Studies on lipid peroxidation in the rat brain. Neurochemical Research, vol. 19, no. 3, pp. 283-288. http://dx.doi.org/10.1007/ BF00971576. PMid:8177367.

DANKISHIYA, A.S., OBOH, A. and IBRAHIM, U.B., 2013. The prevalence of Helminth parasites in the gastro-intestinal tract of wild African sharptooth catfish Clarias gariepinus (Siluriformes: Clariidae) in Gwagwalada, Nigeria. Research Journal of the Costa Rican Distance Education University. vol. 5, no. 1, pp. 83-87.

DOHERTY, V.F. and OTITOLOJU, A.A., 2016. Occurrence and distribution of monocyclic aromatic hydrocarbons (BTEX) and the impact on macrobenthic community structure in Lagos Lagoon, Nigeria. Environmental Monitoring and Assessment, vol. 188, no. 10, pp. 571. http://dx.doi.org/10.1007/s10661-016-5576-9. PMid:27640166.

DURAND, C., RUBAN, V., AMBLÈS, O.A. and OUDOT, J., 2004. Characterization of the organic matter of sludge: determination of lipids, hydrocarbons and PAH from road retention/infiltration ponds 
in France. Environmental Pollution, vol. 132, no. 3, pp. 375-384. http://dx.doi.org/10.1016/j.envpol.2004.05.038. PMid:15325453.

ELLMAN, G.L., 1959. Tissue sulphydryl groups. Archives of Biochemistry and Biophysics, vol. 82, no. 1, pp. 70-77. http:// dx.doi.org/10.1016/0003-9861(59)90090-6. PMid:13650640.

EMERE, M.C. and EGBE, N.E.L., 2006. Protozoan parasites of Synodontis clarias (A fresh water fish) in River Kaduna. BEST Journal, vol. 3, no. 3, pp. 58-64.

EMERE, M.C., 2000. Parasitic infection of the Nile perch Lates niloticus (L) in River Kaduna. Journal of Aquatic Sciences, vol. 15, no. 1, pp. 51-54. http://dx.doi.org/10.4314/jas.v15i1.19988.

ENUNEKU, A.A. and ILEGOMAH, B.O., 2015. Concentrations of BTEX in shrimps of Ovwian-Udu River, Warri, Delta State, Nigeria and human health implications. European International Journal of Science and Technology, vol. 4, no. 7, pp. 32-40.

EZEWANJI, N.E., AGUIGWO, J.N.I., PHILIP, C.O. and EZEWANJI, H.M.G., 2005. Helminthendo-parasites of mochokids in a tropical rainforest river system. Annual Research International, vol. 2, no. 2, pp. 346-352.

FAROMBI, E.O., ADELOWO, O.A. and AJIMOKO, Y.R., 2007. Biomarkers of oxidative stress and heavy metals levels as indicators of environmental pollution in African cat fish (Clarias gariepinus) from Nigeria Ogun River. International Journal of Environmental Research and Public Health, vol. 4, no. 2, pp. 158-162. http:// dx.doi.org/10.3390/ijerph2007040011. PMid:17617680.

FEDERAL ENVIRONMENTAL PROTECTION AGENCY FEPA, 2003. Guidelines and standards for environmental pollution control in Nigeria, Nigeria: FEPA, 420 p.

FESSLER, D.M.T., 2002. Reproductive Immunosuppression and Diet: An evolutionary perspective on pregnancy sickness and meat consumption. Current Anthropology, vol. 43, no. 1, pp. 19-61. http://dx.doi.org/10.1086/324128. PMid:14992226.

GUIMARAES, C.S., CUSTODIO, D., DE OLIVEIRA, R.C., VARANDAS, L.S. and ARBILLA, G., 2010. Comparative study of automotive aircraft and biogenic emissions of aldehydes and aromatic compounds. Bulletin of Environmental Contamination and Toxicology, vol. 84, no. 2, pp. 180-184. http://dx.doi.org/10.1007/ s00128-009-9891-5. PMid:19806281.

GUIMARÃES, E.F., REGO, E.C.P., CUNHA, H.C.M., RODRIGUES, J.M., and FIGUEROA-VILLAR, J.D., 2014. Certified reference material for traceability in environmental analysis: PAH in toluene. Journal of the Brazilian Chemical Society, vol. 25, no. 2, pp. 351-360.

HANNA, M.I., SHAHEED, I.B. and ELIAS, N.S., 2005. A contribution on chromium and lead toxicity in cultured Oreochromis niloticus. Egyptian Journal of Aquatic Biology, vol. 9, no. 4, pp. 177-209.

IDODO-UMEH, G., 2003. Freshwater Fishes of Nigeria (Taxonomy, Ecological notes, Diet and Utilization). Benin City, Nigeria: Idodo Umeh Publishers Limited, 408 p.

INTERNATIONALAGENCY FOR RESEARCH ON CANCER - IARC, 1999. Some chemicals that cause tumours of the kidney or urinary bladder in rodents and some other substances. Lyon: IARC, pp. 339-383. Monographs on the Evaluation of Carcinogenic Risks to Humans, vol. 73.

ISIBOR, P.O., 2017. Oxidative stress biomarkers in Clarias gariepinus (Burchel, 1822) exposed to Microcystin-LR. BeniSuef University Journal of Basic and Applied Sciences, vol. 6, no. 1, pp. 69-76. http://dx.doi.org/10.1016/j.bjbas.2017.01.005.
JIANG, Z.Y., HUNT, J.V. and WOLFF, S.P., 1992. Wolf Ferrous ion oxidation in the presence of xylenol orange for detection of lipid hydroperoxide in low density lipoprotein. Analytical Biochemistry, vol. 202, no. 2, pp. 384-389. http://dx.doi.org/10.1016/00032697(92)90122-N. PMid:1519766.

KAOUD, H.A., ZAKI, M.M., EL-DAHSHAN, A.R., SAEID, S. and EL ZORBA, H.Y., 2011. Amelioration the toxic effects of cadmium-exposure in nile tilapia (Oreochromis Niloticus) by using Lemna gibba. Journal of Life Science, vol. 8, no. 1, pp. 185-195.

MARKLUND, S. and MARKLUND, G., 1974. Involvement of the Superoxide anion radical in the autoxidation of pyrogallol and a convenient assay for superoxide dismutase. European Journal of Biochemistry, vol. 47, no. 3, pp. 469-474. http:// dx.doi.org/10.1111/j.1432-1033.1974.tb03714.x. PMid:4215654.

MEADOR, J.P., CASILLAS, E., SLOAN, C.A. and VARANASI, U., 1995. Comparative bioaccumulation of polycyclic aromatic hydrocarbons from sediment by two infaunal invertebrates. Marine Ecology Progress Series, vol. 123, pp. 107-124. http:// dx.doi.org/10.3354/meps123107.

NIEHAUS, W.G. and SAMUELSSON, B., 1968. Formation of malonaldehyde from phospholipid arachidonate during microsomal lipid peroxidation. European Journal of Biochemistry, vol. 6, no. 1, pp. 126-130. http://dx.doi.org/10.1111/j.1432-1033.1968. tb00428.x. PMid:4387188.

OLAOSEBIKAN, B.D. and RAJI, A., 1998. Field guide to Nigerian Freshwater Fishes. New Bussa, Nigeria: Federal College of Freshwater Fisheries Technology. 202 p.

OLIVEIRA-RIBEIRO, C. A., NETO, F. F., MELA, M., SILVA, P. H., RANDI, M. A. F., RABITTO, I. S, ALVES COSTA, J.R.M., and PELLETIER, E., 2006. Hematological findings in neotropical fish Hopliasmalabaricus exposed to sub chronic and dietary doses of methylmercury, inorganic lead, and tributyltin chloride. Journal of Environmental Resources, vol. 101, no. 1, pp. 74-80. PMid:16388797.

OMEJI, S.S.G., 2013. Comparative Study on the endo-parasitic infestation in Clarias gariepinus collected from earthen and concrete ponds in Makurdi, Benue State, Nigeria. IOSR, vol. 2, no. 1, pp. 45-49. http://dx.doi.org/10.9790/2380-0214549.

OSU, C.I. and ASUOHA, A.N., 2010. Polycyclic aromatic (PAH) and benzene, toluene, ethylbenzene, and xylene (BTEX) contamination of soil in automobile mechanic workshops in Port Harcourt metropolis, Rivers State, Nigeria. American Scientist, vol. 6 , no. 9, pp. 242-246.

OTITOLOJU, A. and OLAGOKE, O., 2011. Lipid peroxidation and antioxidant defense enzymes in Clarias gariepinus as useful biomarkers for monitoring exposure to polycyclic aromatic hydrocarbons. Environmental Monitoring and Assessment, vol. 182, no. 1-4, pp. 205-213. http://dx.doi.org/10.1007/s10661-0101870-0. PMid:21213039.

PIANO, A., VALBONESI, P., and FABBRI, E., 2004. Expression of cytoprotective proteins, heat shock protein 70 and metallothioneins, in tissues of Ostrea edulis exposed to heat and PAH. Cell Stress Chaperon, vol. 19, no. 2, pp. 134-142.

QUINLAN, T.R., MARSH, J.P., JANSSEN, Y.M.W., BORM, P.A. and MOSSMAN, B.T., 1994. Oxygen radicals and asbestosmediated disease. Environmental Health Perspectives, vol. 102, no. 10, suppl. 10, pp. 107-110. PMid:7705283.

SALIU, A., ADISE, S., XIAN, S., KUDELSKA, K. and RODRIGUEZ-CONTRERAS, A., 2014. Natural and lesion-induced 
decrease in cell proliferation in medial nucleus of the trapezoid body during hearing development. The Journal of Comparative Neurology, vol. 522, no. 5, pp. 971-985. http://dx.doi.org/10.1002/ cne.23473. PMid:24115041.

SMITH, K.L. and GUENTZEL, J.L., 2010. Mercury concentrations and omega-3 fatty acids in fish and shrimp: preferential consumption for maximum health benefits. Marine Pollution Bulletin, vol. 60, no. 9, pp. 1615-1618. http://dx.doi.org/10.1016/j. marpolbul.2010.06.045. PMid:20633905.

SOARES, M.R. and ALLEONI, L.R.F., 2006. Distribution coefficient (KD) of heavy metals in Brazilian soils. In: 18th World Congress of Soil Sciences, 9-15 July 2006, Philadelphia, Pennsylvania. Philadelphia, Pennsylvania $134 \mathrm{p}$.

SOUFY, H., SOLIMAN, M.K., EL-MANAKHLY, E.M. and GAAFAR, A.Y., 2007. Some biochemical and pathological investigations on monosex Tilapia following chronic exposure to carbofuran pesticides. Global Veterinaria, vol. 1, pp. 45-52.

SOUNDARARAJAN, M., VEERAIYAN, G. and SAMIPILLAI, S.S., 2009. Anthracene-induced oxidative stress in fresh water tilapia (Tilapia mossambica). Journal of Phytology, vol. 1, no. 4, pp. 267-276.

VIARENGO, A., 1989. Heavy metals in marine invertebrates, mechanisms of regulation and toxicity at cellular concentrations. Revised Aquatic Scienc, vol. 1, pp. 295-317.

VIJAYAVEL, K., GOMATHI, R.D., DURGABHAVANI, K. and BALASUBRAMANIAN, M.P., 2004. Sublethal effect of naphthalene on lipid peroxidation and antioxidant status in the edible marine crab Scylla serrata. Elsevier. Journal of Marine Pollution Bulletin, vol. 48, no. 5-6, pp. 429-433. http://dx.doi. org/10.1016/j.marpolbul.2003.08.017. PMid:14980458. 